\title{
META ANALISIS: FAKTOR-FAKTOR YANG MEMPENGARUHI KUALITAS AUDIT PADA APARAT PENGAWASAN INTERNAL PEMERINTAH (APIP) DI INDONESIA
}

\author{
Dandy Evan Kiswara 1*, Iswajuni 2 Cintya Handayani 3, Soegeng Soetedjo 4 \\ *Badan Pengawas Internal, University of Airlangga \\ Airlangga 4-6 Street, Surabaya, Indonesia \\ E-mail: d.evankiswara@gmail.com
}

\begin{abstract}
Abstrak
Penelitian ini bertujuan untuk menentukan faktor-faktor yang mempengaruhi kualitas audit pada Aparat Pengawasan Internal Pemerintah (APIP) dengan menggunakan 7 tahun data penelitian dari jurnal Indonesia yang dipublikasi. Penelitian ini menguji pengaruh antara kompetensi, independensi, motivasi, pengalaman kerja, obyektifitas, integritas, etika auditor, profesionalisme, dan akuntabilitas terhadap kualitas audit pada APIP. Penelitian ini mengakumulasi dan mengintegrasikan studi yang telah ada menggunakan teknik meta-analisis yang dikembangkan oleh Hunter et al. (1982) terhadap 20 artikel sampel yang dipublikasi antara tahun 20112018. Artikel yang digunakan adalah artikel yang meneliti tentang faktor-faktor yang mempengaruhi kualitas audit pada APIP dalam hal ini adalah Inspektorat dan BPKP. Hasil penelitian ini menunjukkan bahwa kompetensi, independensi, motivasi, pengalaman kerja, obyektifitas, integritas, etika auditor, profesionalisme, dan akuntabilitas adalah faktor yang memiliki hubungan signifikan dengan kualitas audit pada APIP. Berdasarkan hal tersebut, maka terdapat 9 variabel yang memiliki hubungan kuat sebagai faktor yang mempengaruhi kualitas audit pada APIP. Penelitian ini adalah studi terintegrasi yang sebelumnya belum pernah dilakukan pada kualitas audit pada APIP.
\end{abstract}

\section{Kata kunci: Kualitas Audit, Meta-Analisis, Faktor-Faktor yang Mempengaruhi Kualitas Audit, Audit} Bidang SDM, Audit Keuangan

\begin{abstract}
This research try to study the determinants of audit quality with 7 years data from published journals in Indonesia. The purpose of this research is to examine the association between competency, independence, motivation, work experience, objectivity, integrity, ethical auditors, professionalism, and accountability to audit quality. This research applies the meta-analysis technique developed by Hunter et al. (1982) to a sample of 20 articles published from 2011 until 2018. This research used are articles that examine the factors that affect the quality of audit at Aparat Pengawasan Internal Pemerintah (APIP) in this case is Inspektorat and BPKP. This research shows that competency, independence, motivation, work experience, objectivity, integrity, ethical auditors, professionalism, and accountability are the factors which significantly associate with the audit quality at APIP. Based on this results, there are 9 variables that have a strong relationship as a factors that affects the quality of audit on APIP. This study is an integrated study that had not previously been done on audit quality in APIP.
\end{abstract}

Keywords: Audit quality, Meta-Analysis, Determinants of audit quality, HRM Audit, Finance Audit, Quality 


\section{Pendahuluan}

\subsection{Latar Belakang}

Peraturan Menteri Negara Pendayagunaan Aparatur Negara nomor 5 tahun 2008 tentang Standar Audit Aparat Pengawasan Internal Pemerintah (APIP) menjelaskan bahwa APIP adalah Instansi Pemerintah yang mempunyai tugas pokok dan fungsi melakukan pengawasan dan terdiri atas:

a. Badan Pengawasan Keuangan dan Pembangunan (BPKP) yang bertanggung jawab kepada Presiden

b. Inspektorat Jenderal (Itjen)/Inspektorat Utama (Ittama)/Inspektorat yang bertanggung jawab kepada Menteri/Kepala Lembaga Pemerintah Non Departemen (LPND)

c. Inspektorat Pemerintah Provinsi yang bertanggung jawab kepada Gubernur, dan;

d. Inspektorat Pemerintah Kabupaten/Kota yang bertanggung jawab kepada Bupati/Walikota

PERMENPAN tersebut mendefinisikan bahwa pengertian standar audit adalah kriteria atau ukuran mutu minimal untuk melakukan kegiatan audit yang wajib dan menjadi pedoman bagi APIP. Tujuan dari penyusunan standar audit tersebut adalah untuk:

a. menetapkan prinsip-prinsip dasar yang merepresentasikan praktik-praktik audit yang seharusnya

b. menyediakan kerangka kerja pelaksanaan dan peningkatan kegiatan audit intern yang memiliki nilai tambah

c. menetapkan dasar-dasar pengukuran kinerja audit

d. mempercepat perbaikan kegiatan operasi dan proses organisasi

e. menilai, mengarahkan dan mendorong auditor untuk mencapai tujuan audit

f. menjadi pedoman dalam pekerjaan audit

g. menjadi dasar penilaian keberhasilan pekerjaan audit

Standar audit tersebut merupakan suatu ukuran mutu minimal yang berfungsi dalam pelaksanaan tugas pokok dan fungsi yang dapat merepresentasikan praktik-praktik audit, menyediakan kerangka kerja pelaksanaan dan peningkatan kegiatan audit yang memiliki nilai tambah serta menetapkan dasar-dasar pengukuran kinerja audit termasuk penilaian efektifitas tindak lanjut hasil pengawasan dan konsistensi penyajian laporan hasil audit. Pada hakikatnya, standar audit merupakan suatu standarisasi yang digunakan sebagai ukuran mutu atau kualitas audit audit bagi APIP dalam melaksanakan tugasnya. De Angelo (1981) dalam Saputra et al. (2015) mendefinisikan kualitas audit sebagai probabilitas bahwa auditor akan menemukan dan melaporkan pelanggaran pada sistem akuntansi klien. Untuk menemukan pelanggaran tergantung pada kemampuan teknis auditor. Menurut Setyani \& Fauzan (2015) independensi merupakan dasar dari profesi auditor, independensi mampu membuat auditor bersikap netral dan objektif terhadap entitas yang diaudit. Kualitas audit adalah indikator yang menjadi pertimbangan dalam pengambilan keputusan, karena menjadikan tolok ukur kemampuan dari auditor dalam melaksanakan tugasnya sesuai dengan Standar Audit.

Mengingat begitu banyaknya faktor-faktor yang mempengaruhi kualitas audit diantaranya adalah kompetensi (KO), independensi (ID), motivasi $(\mathrm{MV})$, pengalaman kerja (PK), obyektifitas (OB), integritas (IN), etika auditor (EA), profesionalisme (PF), dan akuntabilitas (AK).

Terdapat inkonsistensi dari penelitian-penelitian sebelumnya pada faktor-faktor yang mempengaruhi kualitas audit diantaranya pada penelitian Precilia Prima (2012) dan Made Fandy (2015) pada variable independensi memiliki hasil berkebalikan yang satu berpengaruh positif dan yang satu berpengaruh negatif. Berdasarkan hal tersebut, penelitian ini bertujuan untuk melakukan studi secara menyeluruh terhadap faktor-faktor yang mempengaruhi kualitas audit melalui sebuah studi komprehensif untuk menemukan variabel-variabel yang memiliki hubungan yang kuat dengan kualitas audit. Studi meta analisis dipilih sebagai metode untuk permasalahan ini. Meta analisis merupakan teknik statistik yang digunakan agar peneliti dapat mengatasi kekurangan aspek narasi dari penelitian empiris, dengan cara mengakumulasi penemuan statistik dari beberapa penelitian yang saling berhubungan dalam suatu percobaan untuk membuat generalisasi kuantitatif dan mengurangi kelemahan statistik dari studi dengan ukuran sampel yang kecil (Ahmed et al., 2013).

\subsection{Rumusan Masalah}

Pada penelitian ini, rumusan masalahnya adalah faktor-faktor apa saja yang mempengaruhi kualitas audit pada APIP?

\subsection{Tujuan Penelitian}

Untuk mengetahui faktor-faktor yang memengaruhi kualitas audit pada APIP

\subsection{Manfaat Penelitian}

Secara teoritis, penelitan ini diharapkan dapat menambah dan memperluas konsep dan teori pada penelitian tentang kualitas audit pada APIP. Secara empiris, dengan mengetahui faktor yang mempengaruhi kualitas audit pada APIP. Secara kebijakan, penelitian ini dapat membantu dalam pengambilan keputusan dan sebagai pertimbangan dalam meningkatkan mutu atau kualitas audit pada 


\section{Tinjauan Pustaka}

\subsection{Teori Agensi}

Jensen dan Meckling (1976) mendefinisikan hubungan keagenan sebagai kontrak yang dilakukan oleh seseorang atau lebih sebagai principal (Instansi) dengan agent (APIP) untuk melakukan pendelegasian wewenang pengambilan keputusan dari Instansi atau pemerintah kepada APIP. Untuk mengawasi perilaku agent serta menyelaraskan tujuan principal dan agent, principal mewajibkan agent untuk mempertanggungjawabkan sumber daya yang dipercayakan kepadanya melalui mekanisme pelaporan keuangan sebagai kinerja agent (Scott, 2003 dalam Rohman 2009). Melalui laporan keuangan yang merupakan tanggung jawab agent, principal dapat mengukur, menilai sekaligus mengawasi kinerja agent, sejauh mana agent telah bertindak untuk meningkatkan kesejahteraan principal (Rohman, 2009).

\subsection{Teori Sinyal}

Menurut Sari dan Zuhrotun (2006), teori sinyal menjelaskan tentang bagaimana seharusnya perusahaan memberikan sinyal kepada pengguna laporan keuangan. Jika dihubungkan dengan teori keagenan yang telah dibahas sebelumnya, teori sinyal secara umum membahas tentang bagaimana seharusnya sinyal-sinyal keberhasilan yang dicapai menajemen beserta kegagalan yang dialaminya disampaikan kepada principal.

\subsection{Kualitas Audit}

Kualitas audit merupakan fungsi jaminan dimana kualitas tersebut akan digunakan untuk membandingkan kondisi yang sebenarnya dengan kondisi yang seharusnya (Septriani, 2013). Pengukuran kualitas audit oleh Aparat Pengawas Internal Pemerintah (APIP) dalam Peraturan Menteri Negara Pendayagunaan Aparatur Negara, PER/05/M.PAN/03/2008, wajib menggunakan Standar Pemeriksaan Keuangan Negara (SPKN). Standar Pemeriksaan Keuangan Negara (2007) menyatakan kualitas audit yaitu hasil pemeriksaan yang memuat adanya kelemahan dalam pengendalian intern, kecurangan, penyimpangan dari ketentuan peraturan perundang-undangan, dan ketidakpatutan, yang dilengkapi tanggapan dari pimpinan atau pejabat yang

bertanggung jawab pada entitas yang diperiksa. Tanggapan berhubungan mengenai temuan, dan rekomondasi serta tindakan koreksi yang direncanakan.

\subsection{Faktor-Faktor yang Mempengaruhi Kualitas Audit Pada APIP di Indonesia}

Banyak penelitian di Indonesia yang membahas tentang faktor-faktor yang mempengaruhi kualitas audit APIP di Indonesia. Kualitas audit menjadi patokan bagi pengguna informasi dalam membuat keputusan bagi suatu instansi ke depannya. Faktorfaktor yang mempengaruhi kualitas audit APIP antara lain adalah kompetensi $(\mathrm{KO})$, independensi (ID), motivasi (MV), pengalaman kerja (PK), objektivitas (OB), integritas (IN), etika auditor (EA), akuntabilitas (AK), dan profesionalisme (PF). Dari penelitian yang ada, telah ditemukan hasil yang tidak konsisten antara penelitian satu dengan yang lain sebagaimana ditunjukkan tabel 1 berikut ini:

TABEL 1

RINGKASAN HASIL PENELITIAN INKOSISTEN SEBELUMNYA

\begin{tabular}{|c|c|c|c|c|}
\hline No & Variabel & Hubungan Positif & Hubungan Negatif & Tidak Signifikan \\
\hline 1 & $\begin{array}{l}\text { Kompetensi } \\
(\mathrm{KO})\end{array}$ & $\begin{array}{l}\text { Murtapa dan I Ketut Budiartha ( 2017), } \\
\text { Andy Dwi Cahyono et al (2015), Jasman } \\
\text { et al (2016), Precilia Prima Queena \& } \\
\text { Abdul Rohman (2012), Dermawan et al } \\
\text { (2018), Yunus Fiscal et al (2012), Made } \\
\text { Fandy Permana Putra et al } \\
\text { (2015),Mohamad Adiguna et al (2015), } \\
\text { Ni Wayan Nistri Wirasuasti et al (2014), } \\
\text { Komang Gunayanti Ariani dan I Dewa } \\
\text { Nyoman Badera (2015), Achmad Badjuri } \\
\text { (2012), Rita Anugerah et al (2014), } \\
\text { Afridian Wirahadi Ahmad et al (2011), } \\
\text { Ainia Salsabila dan Hepi Prayudiawan } \\
\text { (2011) }\end{array}$ & & $\begin{array}{l}\text { Marietta Sylvie } \\
\text { Bolang et al (2013), } \\
\text { Annisa Parasayu } \\
\text { dan Abdul Rohman } \\
(2014)\end{array}$ \\
\hline
\end{tabular}




\begin{tabular}{|c|c|c|c|c|}
\hline No & Variabel & Hubungan Positif & Hubungan Negatif & Tidak Signifikan \\
\hline 2 & $\begin{array}{l}\text { Independensi } \\
\text { (ID) }\end{array}$ & $\begin{array}{l}\text { Murtapa dan I Ketut Budiartha ( } 2017) \text {, } \\
\text { Andy Dwi Cahyono et al (2015), Jasman } \\
\text { et al (2016), Dermawan et al (2018), } \\
\text { Made Fandy Permana Putra et al (2015), } \\
\text { Mohamad Adiguna et al (2015), Marietta } \\
\text { Sylvie Bolang et al (2013), Ni Wayan } \\
\text { Nistri Wirasuasti et al (2014), Afridian } \\
\text { Wirahadi Ahmad et al (2011) }\end{array}$ & & $\begin{array}{lr}\text { Precilia } & \text { Prima } \\
\text { Queena \& } & \text { Abdul } \\
\text { Rohman } & (2012), \\
\text { Achmad } & \text { Badjuri } \\
(2012), & \text { Annisa } \\
\text { Parasayu dan Abdul } \\
\text { Rohman (2014) }\end{array}$ \\
\hline 3 & $\begin{array}{l}\text { Etika } \\
\text { Auditor (EA) }\end{array}$ & $\begin{array}{l}\text { Murtapa dan I Ketut Budiartha ( 2017), } \\
\text { Jasman et al (2016), Precilia Prima } \\
\text { Queena \& Abdul Rohman (2012), Ridho } \\
\text { Hidayat et al (2014), Annisa Parasayu } \\
\text { dan Abdul Rohman (2014) }\end{array}$ & & $\begin{array}{l}\text { Ditiya Himawati et } \\
\text { al (2017) }\end{array}$ \\
\hline 4 & $\begin{array}{l}\text { Obyektivitas } \\
\text { (OB) }\end{array}$ & $\begin{array}{l}\text { Andy Dwi Cahyono et al (2015), Precilia } \\
\text { Prima Queena \& Abdul Rohman (2012), } \\
\text { Komang Gunayanti Ariani dan I Dewa } \\
\text { Nyoman Badera (2015) }\end{array}$ & & $\begin{array}{l}\text { Ditiya Himawati et } \\
\text { al (2017), Achmad } \\
\text { Badjuri } \\
\text { Annisar Parasayu } \\
\text { dan Abdul Rohman } \\
(2014)\end{array}$ \\
\hline No & Variabel & Hubungan Positif & Hubungan Negatif & Tidak Signifikan \\
\hline 5 & $\begin{array}{l}\text { Integritas } \\
\text { (IN) }\end{array}$ & $\begin{array}{l}\text { Andy Dwi Cahyono et al (2015), Precilia } \\
\text { Prima Queena \& Abdul Rohman (2012), } \\
\text { Ridho Hidayat et al (2014), Komang } \\
\text { Gunayanti Ariani dan I Dewa Nyoman } \\
\text { Badera (2015), Achmad Badjuri (2012), } \\
\text { Annisa Parasayu dan Abdul Rohman } \\
\text { (2014) }\end{array}$ & & $\begin{array}{l}\text { Ditiya Himawati et } \\
\text { al (2017) }\end{array}$ \\
\hline 6 & $\begin{array}{l}\text { Pengalaman } \\
\text { Kerja (PK) }\end{array}$ & $\begin{array}{l}\text { Yunus Fiscal et al (2012), Made Fandy } \\
\text { Permana Putra et al (2015), Ridho } \\
\text { Hidayat et al (2014), Marietta Sylvie } \\
\text { Bolang et al (2013), Annisa Parasayu dan } \\
\text { Abdul Rohman (2014), }\end{array}$ & & $\begin{array}{lr}\text { Precilia } & \\
\text { Queena } & \text { Prima } \\
\text { Rohman } & \text { Abdul } \\
\text { Achmad } & \text { Badjuri } \\
(2012) & \end{array}$ \\
\hline 7 & $\begin{array}{l}\text { Akuntabilitas } \\
\text { (AK) }\end{array}$ & $\begin{array}{l}\text { Mohamad Adiguna et al (2015), Ainia } \\
\text { Salsabila dan Hepi Prayudiawan (2011) }\end{array}$ & & \\
\hline 8 & $\begin{array}{l}\text { Profesional } \\
(\mathrm{PF})\end{array}$ & Ida Rosnidah et al (2011) & $\begin{array}{l}\text { Precilia Prima } \\
\text { Queena \& Abdul } \\
\text { Rohman (2012) }\end{array}$ & $\begin{array}{l}\text { Mohamad Adiguna } \\
\text { et al (2015) }\end{array}$ \\
\hline 9 & $\begin{array}{l}\text { Motivasi } \\
\text { (MV) }\end{array}$ & $\begin{array}{l}\text { Ridho Hidayat et al (2014), Ni Wayan } \\
\text { Nistri Wirasuasti et al (2014) }\end{array}$ & & $\begin{array}{l}\text { Ida Rosnidah et al } \\
\text { (2011) }\end{array}$ \\
\hline
\end{tabular}

Sumber: Data Yang Diolah

Dari tabel 1 tersebut diketahui bahwa ada beberapa penelitian yang memiliki variabel sama namun dengan hasil penelitian yang berbeda. Pada variabel kompetensi (KO), independensi (ID), pengalaman kerja (PK), objektivitas (OB), integritas (IN), dan etika auditor (EA), beberapa peneliti menyatakan bahwa variabel tersebut memiliki pengaruh positif terhadap kualitas hasil audit, namun dalam penelitian lain disebutkan bahwa variabel tersebut tidak memiliki pengaruh signifikan terhadap kualitas hasil audit. Maka dari itu diperlukan studi meta analisis untuk mengetahui apakan variabelvariabel tersebut di atas memiliki pengaruh signifikan terhadap kualitas hasil audit. 
Berdasarkan pada tabel 1 diatas, maka dapat dirumuskan hipotesi pada penelitian ini adalah sebagai berikut:

H1: Kompetensi berpengaruh positif terhadap kualitas audit APIP.

$\mathrm{H} 2$ : Independensi berpengaruh positif terhadap kualitas audit APIP

H3: Motivasi berpengaruh positif terhadap kuaitas audit APIP

H4: Pengalaman Kerja berpengaruh positif terhadap kualitas audit APIP

H5: Obyektivitas berpengaruh positif terhadap kualitas audit APIP

H6: Integritas berpengaruh positif terhadap kualitas audit APIP

H7: Etika auditor berpengaruh positif terhadap kualitas audit APIP

H8: Profesional berpengaruh positif terhadap kualitas audit APIP

H9: Akuntabilitas berpengaruh positif terhadap kualitas audit APIP.

\subsection{Kerangka Konseptual}

Berdasarkan hasil yang inkonsisten pada penelitian yang telah disebutkan sebelumnya, penelitian ini akan menguji 9 variabel dari 20 sampel artikel, yang menganalisis hubungan antara faktor-faktor yang mempengaruhi kualitas audit APIP dengan tujuan untuk menemukan faktor yang paling kuat mempengaruhi kualitas audit APIP dan menemukan perbedaan dalam pengukuran variabel independen dan variabel dependen sebagai variabel moderasi pada hasil yang bervariasi pada penelitian kualitas audit sebelumnya. Model penelitian tersebut dapat dilihat pada gambar berikut.

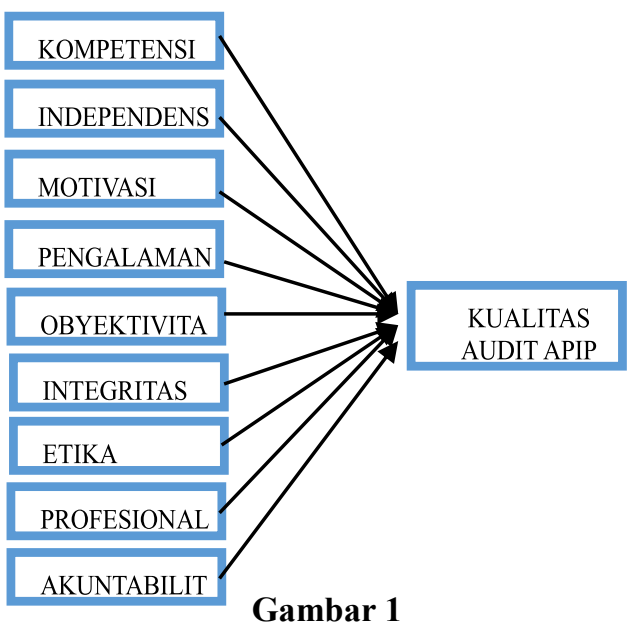

Kerangka Konseptual

Sumber: Hasil Olah Data

\section{Metode Penelitian}

\subsection{Meta Analisis}

Meta-analisis dari korelasi adalah salah satu prosedur metodologi untuk menganalisis secara sistematis literatur yang telah ada untuk membenahi dan memperluas teori yang telah ada (Nair, 2006). Glass (1976) menyatakan bahwa diperlukan sebuah metode yang dapat mengintegrasikan hasil dari studi yang telah ada dan mengungkapkan pola hubungan invariant yang relative dan penyebab perbedaan hasil. Maka dari itu, meta-analisis dapat menjadi salah satu cara untuk menemukan hasil yang lebih valid diantara hasil penelitian yang tidak konsisten.

Penelitian ini memuat analisis koefisien korelasi Pearson dan hitungan dari koefisien korelasi dengan rumus yang dikembangkan oleh Hunter dan Schmidt (1990). Berdasarkan Hunter dan Schmidt (2004) dalam Pranandari (2013), langkah-langkah yang digunakan dalam meta-analisis adalah:

1. Mencari dan mengumpulkan studi yang telah ada

2. Mengutip informasi yang terdapat didalamnya

3. Melakukan meta-analisis terhadap informasi yang telah didapat

Meta-analisis adalah sebuah studi observasi yang meninjau kembali hasil penelitian yang telah ada tanpa melakukan manipulasi percobaan terhadap datayang ada. Semakin banyak data yang digunakan dalam penelitian ini, maka akan memberikan hasil yang semakin valid.

\subsection{Tipe dan Sumber Data}

Penelitian ini menggunakan data sekunder untuk menganalisis masalah, melakukan pengujian hipotesis, dan menjawab rumusan masalah penelitian. Data sekunder mengacu pada informasi yang dikumpulkan oleh orang lain untuk kemudian dilakukan penelitian kembali. Data tersebut dapat diperoleh dari jurnal, buku, situs internet (world wide web), review literature, atau sumber lain selain aktivitas observasi langsung.

\subsection{Populasi dan Sampel}

Populasi dalam penelitian ini adalah seluruh artikel yang dipublikasikan di jurnal Indonesia yang terakreditasi, paper yang disajikan dalam konferensi internasional, dan JRAA, yang menggunakan kualitas hasil audit sebagai variabel dependen. Penelitian ini akan menggunakan jurnal nilai perusahaan yang dipublikasi dan tidak dipublikasi dengan rentang waktu penelitian 7 tahun sejak 2011 hingga 2018. Observasi dilakukan selama 7 tahun untuk memantau progres dan proses 
perkembangan penelitian tentang kualitas hasil audit selama periode tersebut. Penelitian ini memiliki sampel sebanyak 20 artikel dari populasi 30 artikel.

\subsection{Teknik Analisis Data}

Tekhnik analisis data dalam penelitian ini dijelaskan dalam tiga langkah.Langkah pertama dalam tekhnik analisis data ini adalah menentukan kriteria untuk mendapatkan atikel yang akan diuji dalam penelitian ini. Kedua, mengumpulkan keseluruhan hasil studi untuk memastikan bahwa tidak ada kekurangan dalam prosedur meta-analisis yang akan dilakukan. Terakhir, melakukan pengujian menggunakan meta-analisis.

Terdapat banyak prosedur statistic untuk menyatukan metode meta-analisis yaitu akumulasi korelasi (r), perbedaan terstandar antara $t$-value, mean score (d), Z-score, atau p-value(Glass, 1976, 1977; Hunter et al.,1982; Hunter and Schmidt, 1990; Smith and Glass, 1977).

Penelitian ini menggunakan metode meta-analisis yang digunakan oleh Soussii dan Khlif (2010), dan Ahmed et.al. (2012). Keduanya mengikuti metode yang disusun oleh Hunter et al. (1982).

Langkah pertama berdasarkan Hunter et al. (1982) adalah menentukan rata-rata korelasi $(\bar{r})$ dan estimasi populasi varian dengan rumus sebagai berikut:

$$
\overline{\mathrm{r}}=\frac{\sum\left(\mathrm{N}_{\mathrm{i}} \mathrm{r}_{\mathrm{i}}\right)}{\sum \mathrm{N}_{\mathrm{i}}}
$$

dimana $N_{i}$ adalah ukuran sampel untuk studi $i$ dan $r_{i}$ adalah koefisien korelasi Pearson untuk studi $i$.

Ketidakbiasan estimasi varian populasi $S_{p}^{2}$ direpresentasikan dengan:

$$
S_{P}^{2} S_{r}^{2}-S_{e}^{2}
$$

dimana:

$$
\begin{array}{lcc}
S_{r}^{2} & \text { :observasi varian }\left(\sum\left[N_{i}\left(r_{i}-\overline{\mathrm{r}}\right)^{2}\right]\right) / \\
\sum N_{i} & & \\
S_{e}^{2} & \text { :estimasi varian sampling } \operatorname{error}((1- \\
\left.\left.\overline{\mathrm{r}}^{2}\right)^{2} K\right) & N_{i} \\
\mathrm{~K} & \quad \text { : jumlah } & \\
\mathrm{K} &
\end{array}
$$
meta-analisis

Soussii dan Khlif (2011) mengasumsikan bahwa observasi varian $S_{r}^{2}$ telah dijelaskan secara keseluruhan oleh estimasi varian dari sampling error $S_{e}^{2}$, yang menyiratkan bahwa populasi varian populasi $S_{p}^{2}$ dikurangkan menjadi nol.

Di dalam studi sampel, tidak semua artikel menyajikan koefisien Pearson (⿳亠丷厂) tetapi nilai statistic lain, seperti $t$-statistic dan $p$-value atau nilai signifikan. Formula di bawah ini akan menjelaskan bagaimana mengkonversi nilai-nilai tersbut menjadi $r$-statistic:

$$
r_{y \cdot x}=\sqrt{\frac{t^{2}}{t^{2}+d f}}
$$

Setelah di konversi, tanda asli (+/-) dari t-statistic dan koefisien dari $p$-value (signifikansi) harus dimasukan dalam $r_{y . x}(10)$ dan diproses dalam akar kuadrat. Dengan demikian, arah hubungan antar variabel dapat dipertahankan.

Langkah kedua adalah menentukan interval kepercayaan sebesar 95\%. Dengan ukuran sample yang lebih besar dari 30, maka z-statistic ditentukan sebagai berikut:

$$
\begin{aligned}
{\left[\overline{\mathrm{r}}-S_{p} Z 0.975, \overline{\mathrm{r}}\right.} & \left.+S_{p} Z 0.975\right] \\
& \approx\left[\overline{\mathrm{r}}-S_{p}(1.96), \overline{\mathrm{r}}+S_{p}(1.96)\right]
\end{aligned}
$$

Setelah dilakukan dua langkah statistik tersebut, maka akan dihasilkan olahan data yang dapat menjawab uji hipotesis yang telah dibuat. Kriteria pengujian hipotesis dapat dilakukan dalam dua tahap.

Tahap pertama, menentukan hubungan diantara masing-masing variabel independen dengan variabel dependen setelah mengikuti formula (10). Dalam menginterpretasikan signifikansi dan area penerimaan atau penolakan hipotesis, maka digunakan interval kepercayaan pada formula (11). Interval kepercayaan yang digunakan untuk menentukan uji signifikansi hubungan antar variabel adalah 95\%. Hubungan yang signifikan ditunjukkan dengan rentang rata-rata korelasi ( $\overline{\mathrm{r}}$ ) antara area interval kepercayaan dan nilai dari area maksimal dan minimal yang nilainya positif atau negatif semua. Bila tidak demikian, maka hasilnya tidak signifikan terhadap rata-rata korelasi ( $(\overrightarrow{\mathrm{r}})$. Sebagai contoh, jika rata-rata korelasinya (⿳亠丷厂) adalah -0.10 dan level interval kepercayaan $95 \%$ dengan area -0.20 dan +0.50 , maka hasil ini menunjukkan bahwa rata-rata korelasi tidak signifikan. Hipotesis diterima ketika nilai keduanya adalah negatif (-).

Kedua, penetapan nilai positif dan negatif akan mengikuti formula (8) karena penelitian ini menggunakan hipotesis yang langsung memiliki arah. Jika rata-rata korelasi ( $\bar{r})$ memiliki nilai negatif (-) dan interval kepercayaan menunjukkan pengaruh yang signifikan, maka hubungan tersebut akan menjadi negatif dan hipotesis diterima, begitu pula sebaliknya.

\section{Hasil dan Pembahasan}

\subsection{General Meta Analisis}

Studi dari artikel sampel yang terdapat dalam penelitian ini memiliki porsi kontribusi yang berbeda dalam korelasi masing-masing variabel. Hal ini dikarenakan setiap studi menggunakan sampel yang berbeda dan skala pengukuran yang berbeda pada setiap variabel. Maka dari itu untuk 
merepresentasikan dan mengstandarisasikan temuan dari penelitian primer tersebut, maka digunakan indeks ukuran efek (effect size). Effect size (r) menunjukkan besarnya hubungan antara variabel dependen (contoh: kualitas audit) dan variabel independen yang spesifik (contoh: kompetensi,indepedensi).

TABEL 2

EFFECT SIZE $\mathbf{r}$

\begin{tabular}{|c|c|c|c|c|c|c|c|c|c|c|c|c|}
\hline \multirow[b]{2}{*}{$\begin{array}{l}\mathbf{N} \\
\mathbf{O}\end{array}$} & \multirow[b]{2}{*}{ AUTHOR } & \multirow[b]{2}{*}{ PUBLISHER } & \multirow{2}{*}{$\begin{array}{c}\text { Sa } \\
\text { mpl } \\
\mathbf{e}\end{array}$} & \multicolumn{9}{|c|}{ Pearson's Coefficient } \\
\hline & & & & $\mathrm{KO}$ & ID & MV & PK & $\mathrm{OB}$ & IN & EA & $\mathrm{PF}$ & AK \\
\hline 1 & $\begin{array}{c}\text { Ni Wayan } \\
\text { Nistri } \\
\text { Wirasuasti } \\
\text { et al } \\
\text { (2014) }\end{array}$ & $\begin{array}{c}\text { e-Journal S1 Ak } \\
\text { Universitas } \\
\text { Pendidikan } \\
\text { Ganesha,Volum } \\
\text { e } 2 \text { No: } 1 \text { Tahun } \\
2014\end{array}$ & 31 & $\begin{array}{l}0,562 \\
4\end{array}$ & $\begin{array}{l}0,57 \\
42\end{array}$ & $\begin{array}{l}0,40 \\
80\end{array}$ & & & & & & \\
\hline 2 & $\begin{array}{c}\text { Dermawan } \\
\text { et al } \\
(2018)\end{array}$ & $\begin{array}{c}\text { Vol. X. No. } 1 . \\
\text { Januari } 2018 \\
\text { JURNAL } \\
\text { TEPAK } \\
\text { MANAJEMEN } \\
\text { BISNIS }\end{array}$ & 93 & $\begin{array}{l}0,349 \\
0\end{array}$ & $\begin{array}{l}0,22 \\
79\end{array}$ & & & & & & & \\
\hline 3 & $\begin{array}{c}\text { Rita } \\
\text { Anugerah } \\
\text { et al } \\
(2014)\end{array}$ & $\begin{array}{c}\text { Jurnal } \\
\text { Akuntansi, Vol. } \\
\text { 2, No. 2, April } \\
2014: 139-148\end{array}$ & 129 & $\begin{array}{l}0,012 \\
7\end{array}$ & & & & & & & & \\
\hline 4 & $\begin{array}{c}\text { Made } \\
\text { Fandy } \\
\text { Permana } \\
\text { Putra et al } \\
\text { (2015) }\end{array}$ & $\begin{array}{l}\text { e-Journal S1 Ak } \\
\text { Universitas } \\
\text { Pendidikan } \\
\text { Ganesha } \\
\text { Jurusan } \\
\text { Akuntansi } \\
\text { Program S1 } \\
\text { (Volume } 3 \text { No. } 1 \\
\text { Tahun 2015) }\end{array}$ & 40 & $\begin{array}{l}0,467 \\
1\end{array}$ & $\begin{array}{l}0,43 \\
48\end{array}$ & & $\begin{array}{l}0,38 \\
53\end{array}$ & & & & & \\
\hline 5 & $\begin{array}{l}\text { Afridian } \\
\text { Wirahadi } \\
\text { Ahmad et } \\
\text { al (2011) }\end{array}$ & $\begin{array}{c}\text { Jurnal } \\
\text { Akuntansi \& } \\
\text { Manajemen Vol } \\
6 \text { No.2 } \\
\text { Desember } 2011 \\
\text { ISSN 1858-3687 } \\
\text { hal } 63-73\end{array}$ & 26 & $\begin{array}{l}0,417 \\
1\end{array}$ & $\begin{array}{l}0,59 \\
17\end{array}$ & & & & & & & \\
\hline 6 & $\begin{array}{c}\text { Annisa } \\
\text { Parasayu } \\
\text { dan Abdul } \\
\text { Rohman } \\
\text { (2014) }\end{array}$ & $\begin{array}{c}\text { DIPONEGORO } \\
\text { JOURNAL OF } \\
\text { ACCOUNTING } \\
\text {, Volume } 3 \text {, } \\
\text { Nomor 2, Tahun } \\
\text { 2014, Halaman } \\
\text { 1-10 }\end{array}$ & 51 & $\begin{array}{l}(0,27 \\
58)\end{array}$ & $\begin{array}{l}(0,06 \\
06)\end{array}$ & & $\begin{array}{l}0,31 \\
57\end{array}$ & $\begin{array}{l}0,38 \\
79\end{array}$ & $\begin{array}{l}0,31 \\
49\end{array}$ & $\begin{array}{l}0,46 \\
87\end{array}$ & & \\
\hline 7 & $\begin{array}{l}\text { Yunus } \\
\text { Fiscal et al } \\
\text { (2012) }\end{array}$ & $\begin{array}{l}\text { JURNAL } \\
\text { Akuntansi \& } \\
\text { Keuangan }\end{array}$ & 47 & $\begin{array}{l}0,540 \\
8\end{array}$ & & & $\begin{array}{l}0,60 \\
43\end{array}$ & & & & & \\
\hline
\end{tabular}

60 | Jurnal Akuntansi, Ekonomi dan Manajemen Bisnis | Vol. 6 No. 1, July 2018, 54-66 | E-ISSN: 2548-9836 


\begin{tabular}{|c|c|c|c|c|c|c|c|c|c|c|c|c|}
\hline \multirow[b]{2}{*}{$\begin{array}{l}\mathbf{N} \\
\mathbf{O}\end{array}$} & \multirow[b]{2}{*}{ AUTHOR } & \multirow[b]{2}{*}{ PUBLISHER } & \multirow{2}{*}{$\begin{array}{c}\text { Sa } \\
\text { mpl } \\
\text { e }\end{array}$} & \multicolumn{9}{|c|}{ Pearson's Coefficient } \\
\hline & & & & KO & ID & MV & PK & $\mathrm{OB}$ & IN & EA & $\mathrm{PF}$ & $\mathrm{AK}$ \\
\hline & & $\begin{array}{c}\text { Vol. 3, No. 1, } \\
\text { Maret } 2012 \\
\text { Halaman } 69-82\end{array}$ & & & & & & & & & & \\
\hline 8 & $\begin{array}{l}\text { Achmad } \\
\text { Badjuri } \\
(2012)\end{array}$ & $\begin{array}{l}\text { Dinamika } \\
\text { Akuntansi, } \\
\text { Keuangan dan } \\
\text { Perbankan, } \\
\text { Nopember 2012, } \\
\text { Hal: } 120 \text { - } 135 \\
\text { Vol. 1, No. } 2 \\
\text { ISSN: 1979- } \\
4878\end{array}$ & 71 & $\begin{array}{l}0,546 \\
8\end{array}$ & $\begin{array}{l}0,08 \\
36\end{array}$ & & $\begin{array}{l}(0,11 \\
07)\end{array}$ & $\begin{array}{l}0,18 \\
02\end{array}$ & $\begin{array}{l}0,30 \\
17\end{array}$ & & & \\
\hline 9 & $\begin{array}{l}\text { Komang } \\
\text { Gunayanti } \\
\text { Ariani dan } \\
\text { I Dewa } \\
\text { Nyoman } \\
\text { Badera } \\
(2015)\end{array}$ & $\begin{array}{c}\text { E-jurnal } \\
\text { Akuntansi } \\
\text { Universitas } \\
\text { Udayana 10.1 } \\
(2015): 182- \\
198\end{array}$ & 45 & $\begin{array}{l}0,092 \\
9\end{array}$ & & & & $\begin{array}{l}0,14 \\
96\end{array}$ & $\begin{array}{l}0,10 \\
08\end{array}$ & & & \\
\hline $\begin{array}{l}1 \\
0\end{array}$ & $\begin{array}{c}\text { Ditiya } \\
\text { Himawati } \\
\text { et al } \\
(2017)\end{array}$ & $\begin{array}{c}\text { FORUM } \\
\text { KEUANGAN } \\
\text { DAN BISNIS } \\
\text { INDONESIA } \\
\text { (FKBI) When } \\
\text { Fintech Meets } \\
\text { Accounting: } \\
\text { Opportunity and } \\
\text { Risk ISBN 978- } \\
\text { 602-17225-7-2. }\end{array}$ & 111 & & & & & $\begin{array}{l}0,02 \\
39\end{array}$ & $\begin{array}{l}0,10 \\
67\end{array}$ & $\begin{array}{l}0,06 \\
78\end{array}$ & & \\
\hline $\begin{array}{l}1 \\
1\end{array}$ & $\begin{array}{c}\text { Ida } \\
\text { Rosnidah } \\
\text { et al } \\
(2011)\end{array}$ & $\begin{array}{l}\text { Pekbis Jurnal, } \\
\text { Vol.3, No.2, Juli } \\
\text { 2011: 456-466 }\end{array}$ & 30 & & & $\begin{array}{l}(0,10 \\
53)\end{array}$ & & & & & $\begin{array}{l}0,59 \\
30\end{array}$ & \\
\hline $\begin{array}{l}1 \\
2\end{array}$ & $\begin{array}{c}\text { Ainia } \\
\text { Salsabila } \\
\text { dan Hepi } \\
\text { Prayudiaw } \\
\text { an (2011) }\end{array}$ & $\begin{array}{c}\text { JURNAL } \\
\text { TELAAH \& } \\
\text { RISET } \\
\text { AKUNTANSI } \\
\text { Vol. 4. No. } 1 \\
\text { Juli 2011 Hal. } \\
155 \text { - } 175\end{array}$ & 68 & $\begin{array}{l}0,357 \\
0\end{array}$ & & & & & & & & $\begin{array}{l}0,36 \\
98\end{array}$ \\
\hline $\begin{array}{l}1 \\
3\end{array}$ & $\begin{array}{c}\text { Mohamad } \\
\text { Adiguna } \\
\text { et al } \\
(2015)\end{array}$ & $\begin{array}{l}\text { JAM13, } \\
\text { 1Diterima, } \\
\text { September } \\
\text { 2014Direvisi, } \\
\text { Desember } \\
\text { 2014Januari } \\
\text { 2015Disetujui, } \\
\text { Februari 2015 }\end{array}$ & 47 & $\begin{array}{l}0,385 \\
6\end{array}$ & \begin{tabular}{|l}
0,41 \\
88
\end{tabular} & & & & & & $\begin{array}{l}(0,06 \\
91)\end{array}$ & $\begin{array}{l}0,72 \\
94\end{array}$ \\
\hline
\end{tabular}




\begin{tabular}{|c|c|c|c|c|c|c|c|c|c|c|c|c|}
\hline \multirow[b]{2}{*}{$\begin{array}{l}\mathbf{N} \\
\mathbf{O}\end{array}$} & \multirow[b]{2}{*}{ AUTHOR } & \multirow[b]{2}{*}{ PUBLISHER } & \multirow{2}{*}{$\begin{array}{c}\text { Sa } \\
\text { mpl } \\
\text { e }\end{array}$} & \multicolumn{9}{|c|}{ Pearson's Coefficient } \\
\hline & & & & KO & ID & MV & PK & OB & IN & EA & $\mathrm{PF}$ & AK \\
\hline $\begin{array}{l}1 \\
4\end{array}$ & $\begin{array}{l}\text { Marietta } \\
\text { Sylvie } \\
\text { Bolang et } \\
\text { al (2013) }\end{array}$ & $\begin{array}{l}\text { Jurnal Riset } \\
\text { Akuntansi dan } \\
\text { Auditing } \\
\text { Magister } \\
\text { Akuntansi } \\
\text { Fakultas } \\
\text { Ekonomi dan } \\
\text { Bisnis Unsrat }\end{array}$ & 36 & $\begin{array}{l}0,068 \\
8\end{array}$ & $\begin{array}{l}0,58 \\
07\end{array}$ & & $\begin{array}{l}0,71 \\
15\end{array}$ & & & & & \\
\hline $\begin{array}{l}1 \\
5\end{array}$ & $\begin{array}{l}\text { Ridho } \\
\text { Hidayat et } \\
\text { al (2014) }\end{array}$ & $\begin{array}{l}\text { JOM FEKON } \\
\text { Vol. } 1 \text { No.2 } \\
\text { Oktober } 2014\end{array}$ & 118 & & & $\begin{array}{l}0,03 \\
73\end{array}$ & $\begin{array}{l}0,21 \\
82\end{array}$ & & $\begin{array}{l}0,21 \\
52\end{array}$ & $\begin{array}{l}0,25 \\
51\end{array}$ & & \\
\hline $\begin{array}{l}1 \\
6\end{array}$ & $\begin{array}{l}\text { Jasman et } \\
\text { al (2016) }\end{array}$ & $\begin{array}{c}\text { e Jurnal } \\
\text { Katalogis, } \\
\text { Volume } 4 \\
\text { Nomor 4, April } \\
2016 \text { hlm 14-24 }\end{array}$ & 33 & $\begin{array}{l}0,585 \\
1\end{array}$ & $\begin{array}{l}0,40 \\
98\end{array}$ & & & & & $\begin{array}{l}0,46 \\
39\end{array}$ & & \\
\hline $\begin{array}{l}1 \\
7\end{array}$ & $\begin{array}{c}\text { Jaka } \\
\text { Winarna } \\
\text { dan } \\
\text { Havidz } \\
\text { Mabruri } \\
(2015)\end{array}$ & $\begin{array}{c}\text { Journal of Rural } \\
\text { and } \\
\text { Development|V } \\
\text { olume VI No. } 1 \\
\text { Februari } 2015 \\
1\end{array}$ & 66 & $\begin{array}{l}0,275 \\
6\end{array}$ & $\begin{array}{l}(0,01 \\
73)\end{array}$ & & $\begin{array}{l}0,28 \\
07\end{array}$ & $\begin{array}{l}0,25 \\
37\end{array}$ & $\begin{array}{l}0,28 \\
43\end{array}$ & & & \\
\hline $\begin{array}{l}1 \\
8\end{array}$ & $\begin{array}{c}\text { Murtapa } \\
\text { dan I } \\
\text { Ketut } \\
\text { Budiartha } \\
\text { ( 2017) }\end{array}$ & $\begin{array}{c}\text { ISSN: 2302- } \\
8556 \\
\text { E-Jurnal } \\
\text { Akuntansi } \\
\text { Universitas } \\
\text { Udayana } \\
\text { Vol.20.3. } \\
\text { September } \\
\text { (2017): } 2103- \\
2130\end{array}$ & 61 & $\begin{array}{l}0,506 \\
8\end{array}$ & $\begin{array}{l}0,28 \\
34\end{array}$ & & & & & $\begin{array}{l}0,30 \\
18\end{array}$ & & \\
\hline $\begin{array}{l}1 \\
9\end{array}$ & $\begin{array}{l}\text { Precilia } \\
\text { Prima } \\
\text { Queena, } \\
\text { Abdul } \\
\text { Rohman } \\
(2012)\end{array}$ & $\begin{array}{c}\text { DIPONEGORO } \\
\text { JOURNAL OF } \\
\text { ACCOUNTING } \\
\text { Volume 1, } \\
\text { Nomor 2, Tahun } \\
\text { 2012, Halaman } \\
1-12\end{array}$ & 62 & $\begin{array}{l}0,339 \\
6\end{array}$ & $\begin{array}{l}0,18 \\
16\end{array}$ & & $\begin{array}{l}0,22 \\
26\end{array}$ & $\begin{array}{l}0,40 \\
61\end{array}$ & $\begin{array}{l}0,38 \\
54\end{array}$ & $\begin{array}{l}0,32 \\
46\end{array}$ & $\begin{array}{l}0,32 \\
46\end{array}$ & \\
\hline $\begin{array}{l}2 \\
0\end{array}$ & $\begin{array}{c}\text { Andy Dwi } \\
\text { Cahyono } \\
\text { et al } \\
(2015)\end{array}$ & $\begin{array}{c}\text { Reformasi ISSN } \\
2088-7469 \text { vol } 5 \\
\text { no } 12015\end{array}$ & 22 & $\begin{array}{l}0,593 \\
3\end{array}$ & $\begin{array}{l}0,47 \\
79\end{array}$ & & & $\begin{array}{l}0,58 \\
99\end{array}$ & $\begin{array}{l}0,47 \\
43\end{array}$ & & & \\
\hline
\end{tabular}

\section{Sumber: Data yang Diolah}

Dari effect size tersebut kemudian dilakukan langkah selanjutnya yaitu menentukan rentang rata-

rata korelasi dan interval kepercayaan. Tabel dibawah ini menunjukkan hasil dari meta analisis 
TABEL 3

GENERAL META ANALISIS

\begin{tabular}{|l|r|r|r|r|r|r|r|}
\hline $\begin{array}{c}\text { General } \\
\text { Meta } \\
\text { Analisis }\end{array}$ & $\sum \mathbf{N i}$ & \multicolumn{1}{|c|}{$\begin{array}{l}\text { K } \\
\text { study }\end{array}$} & \multicolumn{1}{c|}{$\mathbf{R}$} & \multicolumn{1}{c|}{ Min } & to & \multicolumn{1}{c|}{ Max } & \multicolumn{1}{|c|}{$\mathbf{x 2}$} \\
\hline KO & 928 & \multicolumn{1}{c|}{17} & 0,305 & 0,228 & to & 0,381 & 60,948 \\
\hline ID & 639 & 13 & 0,26079 & 0,213 & to & 0,309 & 30,916 \\
\hline MV & 179 & 3 & 0,07761 & 0,060 & to & 0,095 & 4,635 \\
\hline PK & 491 & 8 & 0,27646 & 0,209 & to & 0,344 & 27,716 \\
\hline OB & 428 & 7 & 0,23048 & 0,207 & to & 0,254 & 12,711 \\
\hline IN & 546 & 8 & 0,24238 & 0,239 & to & 0,246 & 6,905 \\
\hline EA & 436 & 6 & 0,26463 & 0,252 & to & 0,278 & 9,314 \\
\hline PF & 139 & 3 & 0,24941 & 0,165 & to & 0,334 & 9,846 \\
\hline AK & 115 & 2 & 0,51677 & 0,474 & to & 0,560 & 6,691 \\
\hline
\end{tabular}

\section{Sumber: Data yang Diolah}

Analisis terhadap 17 studi yang meneliti pengaruh kompetensi (KO) terhadap kualitas hasil audit, menghasilkan korelasi rata-rata $(\overline{\mathrm{r}})=0,305$ dengan $95 \%$ interval kepercayaan antara 0,228 - 0,381. Hasil ini menunjukkan adanya pengaruh yang signifikan kearah positif antara kompetensi dan kualitas audit. Dengan demikian H1 dapat diterima.

Selanjutnya, studi meta analisis pada variabel independensi menunjukkan adanya pengaruh yang positif dan signifikan terhadap kualitas audit. Terdapat 13 studi yang menghasilkan korelasi ratarata $(\bar{r})=0,2608$ dengan $95 \%$ interval kepercayaan antara 0,213 - 0,309.Maka H2 diterima.

Pada variabel motivasi, diketahui korelasi rata-rata $(\bar{r})=0,0776$ dengan $99 \%$ interval kepercayaan antara $0,060-0,095$, menunjukkan bahwa terdapat hubungan positif dan signifikan terhadap kualitas audit, $\mathrm{H} 3$ diterima.

Variabel pengalaman kerja juga memiliki pengaruh yang positif dan signifikan terhadap kualitas hasil audit, dengan korelasi rata-rata $(\overline{\mathrm{r}})=0,2765$ dan $95 \%$ interval kepercayaan antara 0,209 sampai dengan 0,344 , maka H4 diterima.

Obyektivitas juga memiliki pengaruh yang positif dan signifikan terhadap kualitas hasil audit. H5 diterima dengan korelasi rata-rata $(\stackrel{\mathrm{r}}{)})=0,2305$ dan 95\% interval kepercayaan antara 0,207 sampai dengan 0,254 .

Hasil meta analisis pada tabel 3 menunjukkan bahwa variabel Integritas memiliki nilai $r$ rata-rata sebesar 0,242 dengan 95\% interval kepercayaan antara 0,239 hingga 0,246 yang menunjukkan pengaruh positif signifikan terhadap kualitas audit APIP. H6 diterima.
Hasil meta analisis pada tabel 3 menunjukkan bahwa variabel Etika Auditor memiliki nilai r ratarata sebesar 0,264 dengan $95 \%$ interval kepercayaan antara 0,252 hingga 0,278 yang menunjukkan pengaruh positif signifikan terhadap kualitas audit APIP. H7 diterima.

Hasil meta analisis pada tabel 3 menunjukkan bahwa variabel Profesional memiliki nilai $\mathrm{r}$ ratarata sebesar 0,249 dengan $95 \%$ interval kepercayaan antara 0,165 hingga 0,334 yang menunjukkan pengaruh positif signifikan terhadap kualitas audit APIP. H8 diterima.

Hasil meta analisis pada tabel 3 menunjukkan bahwa variabel Akuntabilitas memiliki nilai $\mathrm{r}$ ratarata sebesar 0,517 dengan $95 \%$ interval kepercayaan antara 0,474 hingga 0,560 yang menunjukkan pengaruh positif signifikan terhadap kualitas audit APIP. H9 diterima.

\section{Kesimpulan dan Saran}

\subsection{Kesimpulan}

Penelitian ini bertujuan untuk menentukan faktorfaktor yang mempengaruhi kualitas audit pada Aparat Pengawasan Internal Pemerintah (APIP) dengan menggunakan 7 tahun data penelitian dari jurnal Indonesia yang dipublikasi. Penelitian ini menguji pengaruh antara kompetensi, independensi, motivasi, pengalaman kerja, obyektifitas, integritas, etika auditor, profesionalisme, dan akuntabilitas terhadap kualitas audit pada APIP. Penelitian ini mengakumulasi dan mengintegrasikan studi yang telah ada menggunakan teknik meta-analisis yang dikembangkan oleh Hunter et al. (1982) terhadap 20 artikel sampel yang dipublikasi antara tahun 
2011-2018. Artikel yang digunakan adalah artikel yang meneliti tentang faktor-faktor yang mempengaruhi kualitas audit pada APIP dalam hal ini adalah Inspektorat dan BPKP. Hasil penelitian ini menunjukkan bahwa kompetensi, independensi, motivasi, pengalaman kerja, obyektifitas, integritas, etika auditor, profesionalisme, dan akuntabilitas adalah faktor yang memiliki hubungan signifikan dengan kualitas audit pada APIP. Berdasarkan hal tersebut, maka terdapat 9 variabel yang memiliki hubungan kuat sebagai faktor yang mempengaruhi kualitas audit pada APIP. Penelitian ini adalah studi terintegrasi yang sebelumnya belum pernah dilakukan pada kualitas audit pada APIP.

\subsection{Keterbatasan Penelitian}

Terdapat beberapa keterbatasan dalam penelitian ini diantaranya adalah sebagai berikut:

1. Tidak semua jurnal yang dipakai dalam penelitian ini berasal dari jurnal yang terakreditasi

2. Tidak terdapat penelitian yang menggunakan metode meta analisis untuk faktor yang mempengaruhi kualitas audit pada APIP.

\subsection{Saran}

Berdasarkan keterbatasan penelitian, penulis menyarankan diantaranya adalah sebagai berikut:

1. Diperlukan banyak penelitian meta analisis yang memiliki topik kualitas audit pada APIP agar dapat menyajikan hasil yang akurat

2. Untuk peneliti selanjutnya, disarankan untuk menambah variabel diantaranya adalah gender, beban kerja, dan remunerasi serta menambah jumlah sampel artikel menjadi lebih banyak dan berasal dari jurnal yang terakreditasi.

\section{Daftar Pustaka}

Adiguna, Mohamad, Arif Satria Dan Gendut Suprayitno. 2015. Faktor-Faktor Yang Mempengaruhi Kualitas Hasil Pemeriksaan (Studi Empiris Pada Inspektorat Kabupaten Bogor). Jurnal Aplikasi Manajemen (Jam), Vol. 13 (1).

Ahmad, Afridian Wirahadi, Fera Sriyunianti, Nurul Fauzi Dan Yosi Septriani. 2011. Pengaruh Kompetensi Dan Independensi Pemeriksa Terhadap Kualitas Hasil Pemeriksaan Dalam Pengawasan Keuangan Daerah: Studi Pada Inspektorat Kabupaten Pasaman. Jurnal Akuntansi \& Manajemen, Vol. 6 (2), 63-73.
Ahmed, Kamran, Keryn Chalmers, Dan Hichem Khlif. 2013. A Meta-Analysis Of Ifrs Adoption Effects. The International Journal Of Accounting, 48(2), 173-217.

Anugerah, Rita Dan Sony Harsono Akbar. 2014. Pengaruh Kompetensi, Kompleksitas Tugas Dan Skeptisme Profesional Terhadap Kualitas Audit. Jurnal Akuntansi, Vol. 2 (2), 139-148.

Ariyani, Komang Gunayanti Dan I Dewa Nyoman Badera. 2015. Pengaruh Integritas, Obyektifitas, Kerahasiaan, Dan Kompetensi Pada Kinerja Auditor Inspektorat Kota Denpasar. E-Jurnal Akuntansi Universitas Udayana 10.1, 182198.

Badjuri, Achmad. 2012. Analysis Faktor-Faktor Yang Mempengaruhi Kualitas Hasil Pemeriksaan Audit Sektor Publik (Studi Empiris Pada Bpkp Perwakilan Jawa Tengah). Dinamika Akuntansi, Keuangan Dan Perbankan, Vol. 1 (2), 120-135.

Bolang, Marrieta Sylvie, Jullie J. Sondakh Dan Jenny Morasa. 2013. Pengaruh Kompetensi, Independensi Dan Pengalaman Terhadap Kualitas Audit Aparat Inspektorat Kota Tomohon Dalam Pengawasan Pengelolaan Keuangan Daerah. Jurnal Riset Akuntansi Dan Auditing Magister Akuntansi Fakultas Ekonomi Unsrat, Vol. 4 (2), 1-15.

Cahyono, Andy Dwi, Andy Fefta Wijaya Dan Tjahjanudin Domai. 2015. Pengaruh Kompetensi, Obyektivitas, Kompleksitas Tugas Dan Integritas Auditor Terhadap Kualitas Audit. Jurnal Reformasi, Vol. 5 (1)

Dhermawan Dan M. Rasuli. 2018. Analisis Pengaruh Kompetensi,Independensi Dan Beban Kerja Terhadap Kualitas Audit Dengan Motivasi Sebagai Variabel Moderasi (Studi Empiris Di Badan Pengawasan Keuangan Dan Pembangunan Perwakilan Provinsi Riau). Jurnal Tepak Bisnis Manajemen, Vol. 10 (1)

Fiscal, Yunus, Justian Suhendra Dan Riswan. 2012. Pengaruh Pengalaman Kerja Dan Kompetensi Auditor Terhadap Kualitas Hasil Pemeriksaan (Studi Kasus Pada Kantor Bpkp Bandar Lampung.). Jurnal Akuntansi Dan Keuangan, Vol. 3 (1), 6982. 
Glass, G. V. 1976. Primary, Secondary, And MetaAnalysis Of Research. Educational Researcher, Vol. 10, 3-8.

Handayani, Cintya. 2015. Meta-Analysis: Faktor Faktor Yang Mempengaruhi Nilai Perusahaan. (Skripsi), Universitas Airlangga, Surabaya.

Hidayat, Ridho, Andreas Dan Elfi Ilham. 2014. Pengaruh Pengalaman Kerja, Etika, Integritas, Dan Motivasi Terhadap Kualitas Audit (Studi Empiris Pada Auditor BPKP Provinsi Riau). Jom Fekon, Vol. 1 (2).

Himawati, Ditiya, Mulatsih, Dan Firdhayanti Putri. 2017. Analisis Faktor-Faktor Yang Mempengaruhi Kualitas Audit Internal Pada Inspektorat Jenderal Kementerian Pekerjaan Umum Dan Perumahan Rakyat. Forum Keuangan Dan Bisnis Indonesia 6, 141-148.

Hunter, J. E., And F. L. Schmidt. 1990. Methods Of Meta-Analysis: Correcting Error And Bias In Research Findings (Beverly Hills, Ca: Sage).

Hunter, J. E., And F. L. Schmidt. 2004. Method Of Meta-Analysis Correcting Error And Bias In Research Finding. California: Sage Publications

Hunter, J.E. 1982. Meta-Analysis: Cumulating Research Findings Accross Studies.Beverly Hills, Ca: Sage Publications

Jasman, Andi Mattulada Amir Dan Mohammad Iqbal. 2016. Pengaruh Kompetensi, Independensi Dan Etika Terhadap Kinerja Aparat Pengawas Intern Pemerintah (Apip) Inspektorat Kabupaten Parigi Moutong. EJurnal Katalogis, Vol. 4 (4), 14-24.

Jensen, M. C. Dan Meckling, W. H. 1976. Theory Of The Firm: Managerial Behavior, Agency Costs, And Ownership Structure. Journal Of Financial Economics, Vol. 3(4), 305-360.

Kode Etik Aparat Pengawasan Intern Pemerintah. Jakarta

Manifesti, Juanita. 2017. Meta Analisis : Faktor Faktor yang Memengaruhi Kualitas Audit di Indonesia. Skripsi, Universitas Airlangga, Surabaya.

Murtapha Dan Ketut Budiarta. 2017. Anallisis Pengaruh Kompetensi, Independensi, Dan
Etika Pada Kualitas Audit Di Perwakilan Badan Pengawasan Keuangan Dan Pembangunan. E-Jurnal Akuntansi Universitas Udayana, Vol. 20 (3), 21032130

Nair, Anand. 2006. Meta-Analysis Of The Relationship Between Quality Management Practices And Firm Performance - Inplications For Quality Management Theory Development. Journal Of Operation Management, Vol. 24, 948975.

Parasayu, Annisa Dan Abdul Rohman. 2014. Analisis Faktor-Faktor Yang Mempengaruhi Kualitas Hasil Audit Internal (Studi Persepsi Aparat Intern Pemerintah Kota Surakarta Dan Kabupaten Boyolali). Diponegoro Journal Of Accounting, Vol. 3 (3), 1-10.

$\begin{array}{crr}\text { Peraturan Menteri } & \text { Negara } & \text { Pendayagunaan } \\ \text { Aparatur } & \text { Negara } & \text { Nomor: } \\ \text { Per/04/M.Pan/03/2008. } & \end{array}$

Peraturan Menteri Negara Pendayagunaan Aparatur Negara Nomor: Per /05 / M.Pan/ 03/ 2008. Standar Audit Aparat Pengawasan Intern Pemerintah. Jakarta

Peraturan Badan Pemeriksa Keuangan Nomor 1 Tahun 2007. Standar Audit Keuangan Negara. Jakarta

Peraturan Badan Pemeriksa Keuangan Nomor 1 Tahun 2017. Standar Audit Keuangan Negara. Jakarta

Pranandari, Fitria. 2013. Meta-Analysis: A Decade Study About The Determinants Of Earnings Response Coefficient (Erc) In Indonesia. (Skripsi), Universitas Airlangga, Surabaya.

Putra, Made Fandy Permana, Edy Sujana Dan Made Pradana Adiputra. 2015. Pengaruh Pengalaman Kerja, Kompetensi Auditor Dan Independensi Terhadap Kualitas Hasil Pemeriksaan (Studi Empiris Pada Kantor Inspektorat Kabupaten Buleleng). EJournal S1 Ak Universitas Pendidikan Ganesha, Vol. 3 (1).

Queena, Precilia Prima Dan Abdul Rohman. 2012. Analisis Faktor- Faktor Yang Mempengaruhi Kualitas Audit Aparat Inspektorat Kota/Kabupaten Di Jawa Tengah. Diponegoro Journal Of Accounting, Vol. 1 (2), 1-12. 
Rohman, A. 2007. Pengaruh Peran Manajerial Pengelola Keuangan Daerah Dan Fungsi Pemeriksaan Intern Terhadap Kinerja Pemerintah Daerah. Jurnal Manajemen Akuntansi Dan Sistem Informasi, Vol. 7 No. 2. Januari.

Rosnidah, Ida, Rawi Dan Kamarudin. 2011. Analisis Dampak Motivasi Dan Profesionalisme Terhadap Kualitas Audit Aparat Inspektorat Dalam Pengawasan Keuangan Daerah (Studi Empiris Pada Pemerintah Kabupaten Cirebon). Pekbis Jurnal, Vol. 3 (2), 456-466.

Salsabila, Ainia Dan Hepi Prayudiawan. 2011. Pengaruh Akuntabilitas, Pengetahuan Audit Dan Gender Terhadap Kualitas Hasil Kerja Auditor Internal (Studi Empiris Pada Inspektorat Wilayah Provinsi Dki Jakarta). Jurnal Telaah \& Riset Akuntansi, Vol. 4 (1), 155-175.

Saputra, Prayudha, Edy Sujana, Dan Desak Nyoman Sri Werastuti. 2015. Pengaruh Gaya Kepemimpinan, Pengalaman Kerja, Dan Tekanan Klien Terhadap Kualitas Audit. Jimat (Jurnal Ilmiah Mahasiswa Akuntansi S1), Vol. 3(1).

Sari, Ratna Candra Dan Zuhrotun. 2006. Keinformatifan Laba Di Pasar Obligasi Dan Saham: Uji Liquidation Option Hypothesis. Padang: Simposium Nasional Akuntansi 9.

Septriani, Yossi. 2013. Pengaruh Independensi Dan Kompetensi Auditor Terhadap Kualitas Audit, Studi Kasus Auditor KAP Di Sumatera Barat. Jurnal Akuntansi Dan Manajemen, Vol. 7(2), 78-100.

Setyani, Ria Dan Fauzan. 2015. Pengaruh Kompetensi, Independensi, Etika, Motivasi, Dan Time Budget Pressure Auditor Terhadap Kualitas Audit (Studi Empiris Pada Auditor Pemerintah Di Inspektorat Kab. Boyolali). Seminar Nasional Dan The 2nd Call For Syariah Paper.

Souissi, Mohsen, Dan Khlif, Hichem. 2010. The Determinants Of Corporate Disclosure: A Meta-Analysis. International Journal Of Accounting Dan Information Management, Vol. 18(3), 198-219.

Winarna, Jaka Dan Havidz Mabruri. 2015. Analisis $\quad$ Faktor-Faktor Yang Mempengaruhi Kualitas Hasil Audit Di Lingkungan Pemerintah Daerah. Journal
Of Rural And Development, Vol VI.

Wirasuasti, Ni Wayan Nistri, Ni Luh Gede Erni Sulindawati, Dan Nyoman Tresna Herawati. 2014. Pengaruh Kompetensi, Independensi, Dan Motivasi Terhadap Kualitas Audit Aparat Inspektorat Dalam Pengawasan Keuangan Daerah (Studi Empiris Pada Inspektorat Pemerintah Kabupaten Bangli Dan Inspektorat Pemerintah Kabupaten Buleleng). Jimat (Jurnal Ilmiah Mahasiswa Akuntansi S1), Vol. 2(1). 